\title{
Application of Forensic Accounting in Nepal
}

\author{
Jitendra Prasad Upadhyay (Ph D) \\ Associate Professor, Nepal Commerce Campus
}

\begin{abstract}
Forensic accounting may not be a new concept in accounting. However it has become significant to all stakeholders like the government, investors and practitioners to regularity bodies. Forensic accounting is closely related to the legal process and has the potential to be involved in proceedings in the civil and criminal courts. It provides an accounting analysis to assist in legal matters forming the basis for discussion, debate and ultimately dispute resolution.

This article presents status of application offorensic accounting in Nepal and recommends steps that should be taken for the enhancement of the utilization of forensic accounting as an effective tool for curtailing fraud and corruption in Nepal at different sectors
\end{abstract}

\section{Introduction}

The word Forensic means "suitable for the court of law" and Accounting means "summarizing and classification of financial position of company in the form of accounts". Thus, Forensics Accounting refers to the science of gathering and presenting financial information in a form that will be accepted by a court of jurisprudence against perpetrators of economic crimes. In other words it refers to financial fraud investigation which include the analysis of accounting records to prove or disprove financial fraud and serving as an expert witness to prove or disprove same. It is also termed as financial forensic and investigative accounting. It is assistance in disputes regarding allegations or suspicion of fraud, which are likely to involve litigation, expert determination, and enquiry by an appropriate authority and investigations of suspected fraud, irregularity or impropriety which could potentially lead to civil, criminal or disciplinary proceedings.

\section{The History of Forensic Accounting}

Need for forensic accounting has been increased rapidly due to increase in fraud and criminal statutes. Especially corporate financial scandals like Enron Bankruptcy (2001), World Com cases (2001), Refeo (2005), Mad-off Pyramid (2008) and Lehman Brothers (2008) have placed forensic accounting into the limelight. In ancient Egypt, forensic accountants who inventoried the "Pharahos" grain, gold and other assets 
were called the "eyes and ears" of the "Pharaohs". Another evidence of the existence of forensic accounting can be traced back to the year 1817 when the accountant who examined the bankrupt's account was required to testify in the court case (Crumbly, 2001).

In the early 1900s, the adoption of the Federal Income Tax created demand for forensic accountants, due to income tax evasion. As a result, the Internal Revenue Service (IRS) developed many of the forensic techniques used to detect tax evaders. One of the first income tax evasion cases uncovered by forensic accountants was that of the infamous gangster, Al Capone. During World War II, the Federal Bureau of Investigation (FBI) employed over 500 forensic accountants who were used to examine and monitor financial transactions (Ziegenfuss, 2003).

As the forensic accounting profession has grown over time, several publications have been produced to provide guidance.

In 1946, Maurice Peloubet, an accountant from New York, published the FIRST article entitled "Forensic Accounting: Its Place in Today's Economy."

The American Institute of Certified Public Accountants (AICPA) issued Practice Aid 7 in 1986, which outlines six areas of litigation services including: damages, antitrust, accounting, valuation, general consulting, and analyses. Currently, there are more than 500 universities have been offering courses in forensic accounting. And many publishers have been published different books regarding forensic accounting.

\section{Where Forensic Accounting can be Applied?}

- Criminal and civil investigations

- $\quad$ Preparation of expert reports, reviews and evidence

- $\quad$ Giving oral evidence in court

- Insolvency and liquidation support investigation

- $\quad$ Fraud prevention and awareness strategies

- Fraud and fund tracing

- $\quad$ Civil and criminal actions regarding fraud and financial irregularities

- Breach of contract

- Breach of warranty, particularly on company acquisitions

- Insurance claims

- $\quad$ Liquidation support

- Regulatory enquiries

- $\quad$ Special and confidential investigations

- Fraud and risk management surveys and reports

A forensic accounting engagement and investigation is typically substantially longer than any other investigation. Continuity of staff on the part of the client is therefore often difficult to maintain. This makes it all the more essential that the forensic accountant conducts his work in a manner which is concise, detailed and documented.

\section{The Key Areas of Forensic Accounting}


The main key areas of Forensic Accounting are:

\section{Fraud Investigation}

The first area of Forensic Accounting is investigation of fraud. Forensic accountants become the detective and work out what went wrong, who did it, how they did it and how much money they've stolen. He/she has to present all analysis in court or to the police.

\section{Commercial Disputes}

The list is endless:

- legal contracts get breached (one party doesn't do what the other party expected)

- $\quad$ construction workers fall off buildings

- $\quad$ slanderous comments get made resulting in loss of business

- $\quad$ employees get sacked unfairly

- $\quad$ people steal copyrighted work but of course claim otherwise

Forensic Accountants have to assess the impact of these disputes and in many cases tragedies.

\section{Insurance Claims}

The next area of forensic accounting is to settle the dispute on insurance. If somebody loses something, they claim it on insurance. If claims are huge then Forensic Accountants have to estimate just how much the loss actually is and to then convince the insurance company that it's accurate.

\section{Family Law}

When couples break-up the financial side of things usually turns nasty pretty quickly as each party lays claim to what is rightfully theirs. The Forensic Accountant has to get in there and assess who has what, checking the assets/liabilities that exist, placing a value on them and then explaining all of that to the lawyers and the couples. And of course, it may all to go court.

\section{Valuations}

When business and partnerships need to break-up or a businessman retires and wants to sell his part of the company to others. In such cases the main work includes:

Valuing a company for a sale (in part or in whole), company valuations for bank purposes to borrow funds, and valuing the shares (or share options) in a company for potential sale or purchase etc.

The challenge here is getting the various parties involved agreeing to the valuation. So the Forensic Accountants have to play great role in this regard.

\section{Business Intelligence}

Business Intelligence is all about providing - to management - insight into 
how their business is running which will help them to focus on where to deploy their resources. Forensic Accountants help management to discover where money is being lost so that a decision to divest (sell) a company can be made.

\section{Data Recovery \& Conversion}

Forensic accounting also helps in recovering data which were lost. Forensic Accountants have qualities of data analysis and convincing power to others.

\section{Need for Forensic Accounting}

Detection of Fraud- It helps to detect fraud, trace the assets (if any) created out of fund embezzlement, gather and review the evidence and interview the employee alleged to have embezzled the funds.

Criminal Investigation- It helps in preparing and presenting evidences to solve the criminal investigation.

Dispute Settlement- It helps in resolving contract disputes, construction claims, product liabilities claims, infringement of patent and trade marks cases, liabilities arising from breach of contracts and so on.

Settlement of Insurance Claims- It helps in settling different claims related to insurance company like consequential loss policy, property loss due to various risks, fidelity insurance and other types of insurance claims.

Monetary Savings- It helps in saving unnecessary spending in the organization.

Job Security and Employment Generation- It helps in creating employment because job involved in this field is currently in high demand. The number of forensic accountants is increasing with their specialized knowledge. Due to an expanding economy and stricter auditing control, forensic accounting jobs are expected to become even more in demand within the next decade.

Time Saving: It helps in saving time of lawyers and attorneys by providing them details information about their clients.

\section{The Qualities of a Professional Forensic Team or Forensic Accountants}

It is essential that a professional forensic team or forensic accountants has:

- Knowledge of the elements of economic crime

- The ability to collect evidence and to exercise proper control over large volumes of documentary evidence

- The appropriate skills and level of relevant experience

- Investigation background

- The ability to work in a team with instructing attorneys and police and have the ability to co-ordinate, manage and administer the litigation support, assemble the documents, and organize meetings

- Knowledge of legal aspects such as the basic rules of evidence relating to admissibility of evidence and the drawing of inferences

- The ability to testify and stand up to cross-examination in a court of law 


\section{Difference between Independent Auditor and Forensic Accountant}

An auditor essentially intends to uncover significant deviations from generally accepted accounting principles (GAAP) and to verify that acceptable accounting and auditing practices have been used in the preparation of the financial statements. The forensic accountant takes a much more skeptical and proactive approach to uncovering fraud, not just verifying what is in the financial statements (Crumbley and Apostolou, 2002).

The independent auditor generally assumes that the client has conformed to GAAP. The independent auditor also follows the guidelines set forth by the generally accepted auditing standards (GAAS). After the audit, they can recommend adjustments to enhance the fairness of the financial reporting.

On the other hand, forensic accountants make no assumptions. The forensic accountant critically assesses the legitimacy of the company's financial transactions and conformity to GAAP. When there is alleged fraud, it is important to engage independent forensic accountants because the current auditors may encounter potential inherent conflicts (Conway and Rouse, 2002).

\section{Technology Used in Forensic Accounting}

Most of the criminals behind fraud use sophisticated technology and accounting tricks to commit complex frauds. This means that the forensic accountants need special technology facilities to uncover fraud. To facilitate the preservation, collection, analysis, and documentation of evidence, forensic accountants can use specialized software and computer hardware. There are many new technologies that allow the investigators to recover deleted files, crack encryptions or codes, and extract and sort data.

Deloitte \& Touché has set up a worldwide network of computer forensic labs for their forensic accountants and technicians (Iwata, 2003).

KPMG Forensic Accounting has developed software that it uses to aid in determining how the fraud was perpetrated. The software prepares a TRACE (Transactional Representation of Assets and Court Evidence) diagram. The TRACE diagram provides a computer-generated graphical and concise summary of a series of transactions, events or structures in an easy-to-read format, to map the flow of funds through the perpetrator's private companies/accounts, identify the parties involved, and provide litigation support to the civil and criminal proceedings (Sing, 1999).

Wet Stone Technologies released the Gargoyle software in May 2003. It was developed to work with the government-sponsored National Software Reference Library (NSRL) database. The NSRL database is a collection of digital file signatures, known as hashes, developed from thousands of common software programs. These hashes allow investigators to check if any alterations have occurred (Piazza, 2003).

A company based out of Houston (called Church Street Technology) has developed a very useful tool for forensic accountants and other crime-fighting agencies. Church Street has developed a method for reconstructing shredded documents electronically, offering a speedier alternative to the laborious task of searching, matching, and pasting strips manually. The process uses proprietary digitizing techniques to scan the shredded paper and then matches them with specialized software. The software 
can even reconstruct documents that have been cross-shred or cut in two directions into tiny pieces (Satov, 2003).

\section{Forensic Accounting in Nepal}

With the development of business world financial scams, frauds and corruption has become a part of our corporate and social life. Modern financial frauds are sophisticated, well organized and so carefully mingled with the facts that it's very tough job to inspect it at a routine glance. Therefore, they require an integrated approach to unveil them and to generate the evidence which will be acceptable for the purpose if establishing accountability in the eyes of Law. This integrated approach is known as Forensic Accounting.

\section{Generally three types of frauds are seen:}

a. Financial Statement Frauds: It is the least common type of fraud occurring least frequently and only in $10 \%$ of all fraud cases worldwide. However it is the most expensive as it leads to huge losses within firms. This type of fraud involves:

$\rightarrow$ Manipulation, falsification, alteration of financial statements and accounting records

$\rightarrow \quad$ Misrepresentation or omission of numbers

$\rightarrow \quad$ Misapplication of accounting principles

$\rightarrow \quad$ Intentionally false, misleading or omitted disclosures

b. Misappropriation of Assets: It is the most common type of fraud and occurs most frequently i.e. about $60 \%$ of all fraud schemes worldwide. However it is the least expensive fraud. This type of frauds involves:

$\rightarrow \quad$ Theft of tangible assets such as money, inventory and services by internal and external parties

$\rightarrow \quad$ Sale of proprietary information

$\rightarrow \quad$ Improper payment made to clients

c. Corruption: It is the most frequently occurring types of fraud and constitutes $30 \%$ if all fraud that has been uncovered worldwide. This type of fraud involves:

$\rightarrow \quad$ Bribery and corruption schemes such as kickbacks and sell company schemes

$\rightarrow \quad$ Making or receiving improper payments

$\rightarrow \quad$ Offering bribes to public or private officials

$\rightarrow \quad$ Aiding and abetting fraud by others

Forensic accounting came into limelight due to increased financial frauds and white-collar crimes. Many financial scams took place in our economy which had shaken the roots of trust on our law and system. 


\section{Top Financial Scams in Nepal}

Some of the major financial scams in Nepal were as follows:

\begin{tabular}{|c|c|c|c|}
\hline $\begin{array}{l}\text { S. } \\
\text { N. }\end{array}$ & Scams & $\begin{array}{l}\text { Amount }(\mathrm{Rs} . \\
\text { in million }\end{array}$ & Reasons \\
\hline 1 & General Finance (2012) & 78.25 & $\begin{array}{l}\text { Lack of Internal control system and } \\
\text { corporate governance } \\
\text { Misappropriation by Managers and } \\
\text { Directors }\end{array}$ \\
\hline 2 & $\begin{array}{l}\text { Capital Merchant Banking and } \\
\text { Finance (2012) }\end{array}$ & 2,500 & $\begin{array}{l}\text { Misappropriation by the MD, took out } \\
\text { loans against weak or without collateral }\end{array}$ \\
\hline 3 & Himalaya Finance (2013) & 58.1 & $\begin{array}{l}\text { Fund embezzlement by Branch Manager, } \\
\text { GM and Chairman }\end{array}$ \\
\hline 4 & Crystal Finance (2012) & 446 & $\begin{array}{l}\text { Lack of Internal control system and } \\
\text { corporate governance } \\
\text { Misappropriation by Directors }\end{array}$ \\
\hline 5 & $\begin{array}{l}\text { Nepal Share Market Bank and } \\
\text { Finance (2011) }\end{array}$ & 2,660 & $\begin{array}{l}\text { Misappropriation by Chairman, GM and } \\
\text { Directors }\end{array}$ \\
\hline 6 & $\begin{array}{l}\text { United Development Bank } \\
(2011)\end{array}$ & 462.2 & $\begin{array}{l}\text { Misappropriation by Chairman and } \\
\text { Directors, bad Corporate Governance and } \\
\text { misuse of funds }\end{array}$ \\
\hline 7 & $\begin{array}{l}\text { Gurkha Development } \\
\text { Bank(2011) }\end{array}$ & 500 & $\begin{array}{l}\text { Bad Corporate Governance, corruptions } \\
\text { and misuse of funds }\end{array}$ \\
\hline 8 & $\begin{array}{l}\text { H \& B Development Bank } \\
(2012)\end{array}$ & 1,090 & $\begin{array}{l}\text { Misappropriation by Managers and take } \\
\text { good for payment cheques }\end{array}$ \\
\hline 9 & $\begin{array}{l}\text { Nepal Sri Lanka Merchant } \\
\text { Bank and Finance (2012) }\end{array}$ & 353.1 & Misappropriation by Directors \\
\hline 10 & $\begin{array}{l}\text { Himalayan Bank (2005) \& } \\
(2012)\end{array}$ & $45.2 \& 56.7$ & $\begin{array}{l}\text { Misappropriation by employees and } \\
\text { embezzlement through Master Card and } \\
\text { Visa by employees }\end{array}$ \\
\hline 11 & Nabil Bank (2011) & 4 & Theft of PIN numbers by employees \\
\hline 12 & $\begin{array}{l}\text { Nepal Police Sudan Scam } \\
(2012)\end{array}$ & 290 & $\begin{array}{l}\text { Embezzlement of funds by Top Police } \\
\text { Officers ( IG, AIG, DIG and others) }\end{array}$ \\
\hline 13 & Sajha Publication (2015) & 5 & $\begin{array}{l}\text { Misappropriation and embezzlement of } \\
\text { funds by MD }\end{array}$ \\
\hline 14 & $\begin{array}{l}\text { Tax Fixation Commission } \\
(2017)\end{array}$ & 21,000 & $\begin{array}{l}\text { Manipulation of tax by waiving it to the } \\
\text { tax payer by the Revenue Department } \\
\text { Chief and Seniors tax Officers }\end{array}$ \\
\hline 15 & Nepal Oil Corporation (2017) & 800 & $\begin{array}{l}\text { Fraud in land purchased by paying } \\
\text { higher price than actual price and } \\
\text { purchased of land situated at the banks of } \\
\text { the rivers }\end{array}$ \\
\hline
\end{tabular}

Sources: National Dailies

To overcome from the above mentioned financial scams it is necessary to apply approaches of forensic accounting in the country. But, it is in initial stage in Nepal. There is no any institution that provides formal education of the frauds in Nepal. In Nepal Commission for the Investigation of Abuse of Authority (CIAA), Department of Money Laundering Investigation (DMAI) and Nepal Investigation Bureau (NIB) have given special focus on the frauds. But, there is no specific education provided by any of the universities in the country. White Collared crime is an ignored area in that sense. 


\section{Conclusions}

Financial frauds and white collar criminal activities are becoming a part and parcel of our day to day life. In present social and corporate life, all the frauds are well organized. So to detect all these frauds and to generate evidence we need an integrated approach of Forensic Accounting, which is a combination of accounting, auditing \& investigative skill and focuses on detecting \& preventing frauds. Forensic Accounting is scientific way to find out the evidence and their utilization in dispute's resolution. This facility is still in beginning or nascent condition in Nepal. If we want to restrict major scandals like Capital Merchant Banking, Nepal Share markets and Banks, Sudan Scam, Tax Fixation Commission, Nepal Oil Corporation and others we have to utilize forensic accounting in best way. Nepal Government should formulate the policies for applying forensic accounting and different universities should include this concept in their syllabus because it has tremendous potential as a new practice area for Nepalese Chartered Accountants and Auditors

\section{References}

Bigler, M. (2001). Computer Forensics Gear. The Internal Auditor, pp 27.

Conway, A. C. \& Robert, W. R. (2002). This is a Job for Superman: Calling in a Forensic

Accountant. The Journal of Corporate Accounting \& Finance, pp 23.

Crumbley, D. L. (2003). Certified Forensic Accountant. American College of Forensic Examiners International, online posting.

Crumbley, D. L. \& Nicholas, A. (2002). Forensic Accounting: A New Growth Area in Accounting. Ohio CPA Journal, July/September 2002, p 16.

Fillmer, S. (2003). Forensic Accounting Defined. www.cris.com/ dfillmer/forensic.htm, online posting.

Golden, T.W., Skalak, S.L. \& Chagton, M.M. (2006). A Guide to Forensic Accounting Investigation. John Wiley \& Sons Ltd., Hobokat, New Jershy

Grippo, F. (2003). Introduction to Forensic Accounting. The National Public Accountant, pp 4.

Ibrahim, M.S. \& Abdullah, M. (2011). An Overview of Forensic Accounting in Malaysia. Department of Financial Accounting \& Auditing, University of Malaya

Institute of Certified Public Accounting Pakistan (ICPAP) (2010). Forensic Accounting, Study Note. Specialization Module 6 SP 611

Nunn, L., Mchuire, B. L., whitcomb, C. \& Jost, E. (2006). Forensic Accounts: Financial Investigation. Journal of Business and Economics Research, Feb, Vol. 4 No.2

Sing, A. (1999). Forensic Accounting: Looking for Clues. Australian CPA, pp 42.

Wells, J. T. (2003). The Fraud Examiners. Journal of Accountancy, pp 76.

Wolosky, H. W. (2004). Forensic Accounting to the Forefront. The Practical Accountant, pp 22.

Ziegenfuss, D. (2003). Forensic Accountants: Hot Old Profession. 